\title{
Rare case of BRAF V600E mutant anaplastic pleomorphic xanthroastrocytoma in a 5-year survivor of acute lymphoblastic leukaemia
}

\author{
Jennifer H Yang, ${ }^{1}$ Suzanne M Tucker, ${ }^{2}$ Michael L Levy, ${ }^{3}$ John Ross Crawford ${ }^{4}$
}

${ }^{1}$ Department of Neuroscienes, University of California San Diego, La Jolla, California, USA 2Department of Pathology, Rady Children's Hospital, San Diego, California, USA

${ }^{3}$ Neurosurgery, University of California San Diego, San Diego, California, USA

${ }^{4}$ Neurosciences and Pediatrics, University of California San Diego, La Jolla, California, USA

\section{Correspondence to} Dr John Ross Crawford; jrcrawford@ucsd.edu

Accepted 11 February 2021
Check for updates

(C) BMJ Publishing Group Limited 2021. No commercial re-use. See rights and permissions. Published by BMJ.

To cite: Yang JH, Tucker SM, Levy ML, et al. BMJ Case Rep 2021;14:e241815. doi:10.1136/bcr-2021241815

\section{DESCRIPTION}

A 20-year-old woman with a history of acute lymphoblastic leukaemia treated at 13 years old with radiation and chemotherapy and a benign cystic mature ovarian teratoma diagnosed at 18 years old presented with 6 weeks of headaches and vomiting. She did not report vision changes or other constitutional symptoms, and her neurological examination was normal. MRI of the brain showed a large right frontal lobe mass with extensive surrounding vasogenic oedema and mass effect with an additional enhancing nodule along the right lateral temporal lobe (figure 1). She underwent gross total resection, and frozen sections demonstrated a hypercellular glial neoplasm with atypical cells, hyperchromatic and pleomorphic nuclei and eosinophilic granular bodies with peak count of 5 mitotic figures per 10 high-power fields (HPF) consistent with an anaplastic pleomorphic xanthoastrocytoma (PXA) WHO grade III (figure 2). ${ }^{1}$ Additional areas especially at the interface of the leptomeninges showed papillary growth pattern. Next-generation sequencing of the tumour detected clinically significant variants in $B R A F$ V600E, ATRX, CDKN2A, CDKN2B and variants of uncertain clinical significance in ROS1, WT1 and KMT2D. The microarray showed a homozygous loss of 9p21.3, which encompasses CDKN2A and $C D K N 2 B$, and high copy gain $(\mathrm{x} 4)$ of chromosome

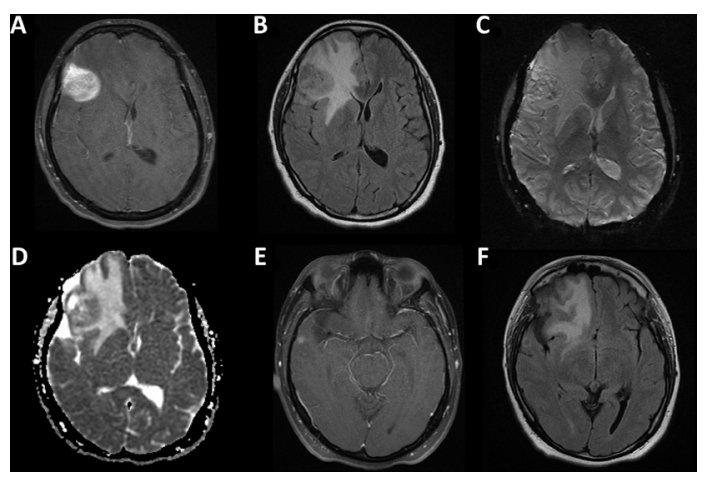

Figure 1 MRI showing mixed solid and cystic mass in the right frontal lobe with extensive vasogenic oedema noted on apparent diffusion coefficient (A) and T2 FLAIR (B and C) with contrast enhancement in the frontal lobe (D). There is additionally an enhancing nodule along the lateral right temporal lobe that may represent a satellite or metastatic nodule (E). There is no associated haemorrhage on susceptibility weight imaging (F). FLAIR, Fluid attenuation inversion recovery.

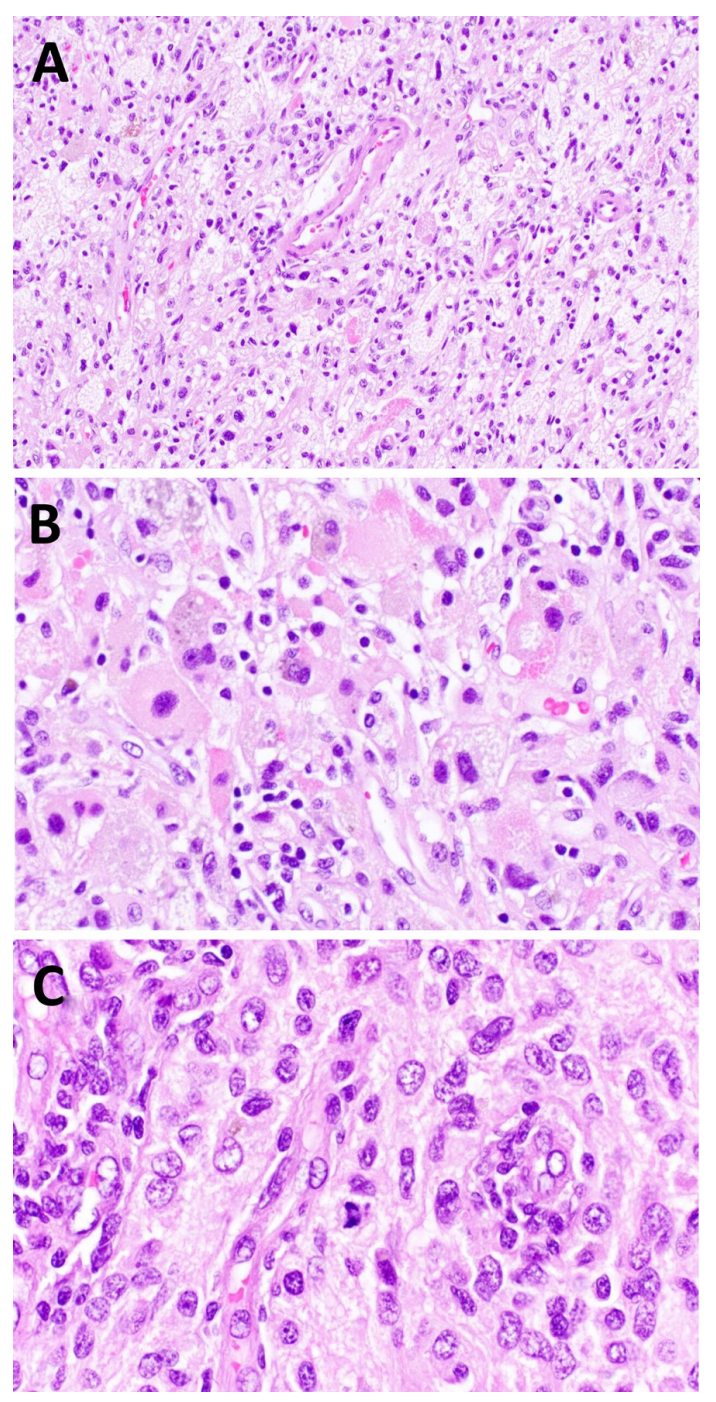

Figure 2 H\&E stained sections showing xanthomatous cells, eosinophilic granular bodies with pleomorphic nuclei (A), pleomorphic cells, eosinophilic granular bodies and lymphocytes (B) and mitotic figure with 5/10 HPF (C). HPF, high-power fields.

7. Additional findings include gains of chromosome 2, 3q26.1-q29 (17 cancer genes), chromosome 4, $5 \mathrm{p} 15.33-\mathrm{q} 31.3$ (20 cancer genes) and chromosomes 12,15 and 20. There was also loss of 8p23.3-q12.1 (15 cancer genes), loss of heterozygosity at $5 \mathrm{q} 31.3$ q35.3 (13 cancer genes), 8q12.1-q24.3 (22 cancer genes) and chromosome 9 .

PXAs are rare brain tumours seen more commonly in children with overall favourable outcomes. ${ }^{1}$ PXA 
with anaplastic features, which are PXAs with mitotic indices $\geq 5 / 10 \mathrm{HPF}$, are now recognised as a separate entity in the revised WHO classification in $2016 .^{2}$ BRAF V600E mutations are found in up to $80 \%$ of supratentorial grade II-III PXAs, ${ }^{3}$ although the incidence of BRAF mutations are less common in anaplastic PXAs. ${ }^{4}$ Deletions in tumour suppressor genes CDKN2A and CDKN2B are common in PXA, observed in 93\% of anaplastic PXAs, and gains within chromosome 7 are seen in $57 \%$ of cases. Other findings include gains in chromosomes 2, 5, 21, 20, 12 and $15 .^{3}$ Malignancies after treatment of childhood leukaemia have been well reported, and risk factors for developing central nervous system (CNS) tumours include prior CNS leukaemia and cranial irradiation in a dose-dependent manner. ${ }^{5-7}$ Our patient's PXA is most likely secondary malignancy related to her prior radiation therapy. Unfortunately, the molecular details regarding the patient's acute lymphoblastic leukaemia (ALL) and ovarian teratoma were unknown as her previous medical care

\section{Learning points}

- Pleomorphic xanthoastrocytomas with anaplastic features are WHO grade III tumours with overall favourable outcomes after surgery.

- BRAF V600E mutations and deletions in CDKN2A and $C D K N 2 B$ are common mutations seen in patients with PXA.

- Patients with a history of childhood leukaemia especially those with radiation therapy should be monitored long term to monitor for development of secondary malignancies. was obtained in another country. Nevertheless, this case adds to the current literature of the rare secondary malignancies associated with previously treated childhood cancer. We report the first case of an anaplastic PXA in association with therapy for acute lymphoblastic leukaemia.

Contributors JHY was responsible for the conception and drafting of the manuscript. SMT was responsible for the conception and drafting of the manuscript. $M L L$ was responsible for the conception and drafting of the manuscript. JRC was responsible for the conception and drafting of the manuscript.

Funding The authors have not declared a specific grant for this research from any funding agency in the public, commercial or not-for-profit sectors.

Competing interests None declared.

Patient consent for publication Obtained.

Provenance and peer review Not commissioned; externally peer reviewed.

\section{REFERENCES}

1 Ida CM, Rodriguez FJ, Burger PC, et al. Pleomorphic xanthoastrocytoma: natural history and long-term follow-up. Brain Pathol 2015;25:575-86.

2 Komori T, The KT. The 2016 who classification of tumours of the central nervous system: the major points of revision. Neurol Med Chir 2017:57:301-11.

3 Vaubel RA, Caron AA, Yamada S, et al. Recurrent copy number alterations in lowgrade and anaplastic pleomorphic xanthoastrocytoma with and without BRAF V600E mutation. Brain Pathol 2018;28:172-82.

4 Phillips JJ, Gong H, Chen K, et al. The genetic landscape of anaplastic pleomorphic xanthoastrocytoma. Brain Pathol 2019;29:85-96.

5 Banerjee J, Pääkkö E, Harila M, et al. Radiation-Induced meningiomas: a shadow in the success story of childhood leukemia. Neuro Oncol 2009;11:543-9.

6 Neglia JP, Meadows AT, Robison LL, et al. Second neoplasms after acute lymphoblastic leukemia in childhood. N Engl J Med 1991;325:1330-6.

7 Walter AW, Hancock ML, Pui CH, et al. Secondary brain tumors in children treated for acute lymphoblastic leukemia at St Jude children's research Hospital. J Clin Oncol 1998;16:3761-7.

Copyright 2021 BMJ Publishing Group. All rights reserved. For permission to reuse any of this content visit

https://www.bmj.com/company/products-services/rights-and-licensing/permissions/

BMJ Case Report Fellows may re-use this article for personal use and teaching without any further permission.

Become a Fellow of BMJ Case Reports today and you can:

- Submit as many cases as you like

- Enjoy fast sympathetic peer review and rapid publication of accepted articles

- Access all the published articles

- Re-use any of the published material for personal use and teaching without further permission

Customer Service

If you have any further queries about your subscription, please contact our customer services team on +44 (0) 2071111105 or via email at support@bmj.com.

Visit casereports.bmj.com for more articles like this and to become a Fellow 